\title{
Environmental Impact Assessment of Kol-Dam Hydropower Project - A Case Study from Himachal Pradesh, India
}

\author{
HUKAM CHAND $^{1 *}$, K. S. VERMA ${ }^{2}$ and TANVI KAPOOR ${ }^{1}$ \\ ${ }^{1}$ Department of Environmental Science, ${ }^{2}$ Dean College of Forestry, \\ Dr.Yashwant Singh Parmar University of Horticulture \& Forestry, Solan (H.P)-173230, India.
}

http://dx.doi.org/10.12944/CWE.11.1.21

(Received: December 19, 2015; Accepted: February 09, 2016)

\begin{abstract}
The study was conducted during 2011 to investigate the impacts of Kol-dam construction on people and their overall economy. There was a loss of total land holding per family in the range of 33.07 to 64.46 per cent in 5 affected villages selected for the study. However in case of cultivated land there was a loss in the range of 36.15 to 67.36 per cent in 5 sampled villages. Submergence of land resulted in the loss of different trees (fodder, timber, fuel wood and fruit) from villages' farmland in the range of 37.45 to 80.60 per cent in 5 affected village. There was a substantial decrease in the livestock population which ranged from 52.50 to 59.60 per cent. Construction of dam resulted in loss of assets to the extent of 33.33 to 45.45 percent in different villages. Overall there was a decrease in on-farm sectors (crop \& livestock) ranged from 42.86 to 81.17 per cent whereas an increase in offfarm income (jobs and private business) ranges from 13.33 - 48.33 per cent has been observed from the affected villages. Hence it can be concluded that there was a loss of on-farm income resources like agriculture land and its associated resources i.e. important tree species and livestock. This might have serious impact on local biodiversity as well as on the life style of project affected families.
\end{abstract}

Key words: Multistage simple random sampling, Satluj, Kol-dam, on-farm, off- farm.

\section{INTRODUCTION}

Himachal Pradesh is endowed with hydroelectric potential of about $27436 \mathrm{MW}$ on the five river basins namely Satluj, Ravi, Beas, Yamuna \& Chenab. The basin wise potential are Satluj (13,332 MW), Beas (5,995 MW), Chenab (4,032 MW), Ravi $(3,237 \mathrm{MW})$ and Yamuna $(840 \mathrm{MW})^{1}$. Although, hydroelectric projects provides opportunities for economic development but also have the potential to adversely affect the livelihood and well-being of local as well as downstream communities in the area ${ }^{2}$. Construction of such projects in this ecologically sensitive Himalayan state has threatened the long term sustainability of the regional bio-diversity, carbon sink and moderate climate ${ }^{3}$. Construction of big dams leads to population displacement as well as change in land use pattern, socio-economic systems, agro-socio-forestry systems, and traditional ecological practices ${ }^{4}$. Hence studies on monitoring \& determining the impact of hydropower projects on people and other resources existing on and around the sites of such projects are necessary for developing plans and policies to rejuvenate the degraded resources. The acquisition of private land along with setting up of the project has been resulted in changes of socio-economic aspects and lifestyle of the local people. Looking in to this, the present 
investigations have been attempted to study the impacts of Kol-dam hydropower project on local people and their overall economy.

\section{MATERIALS AND METHODS}

\section{Study Area}

Kol-Dam hydropower project is located between $31^{\circ} 21^{\prime} 54^{\prime \prime}$ to $31^{\circ} 05^{\prime} 13^{\prime \prime} \mathrm{N}$ latitude and $76^{\circ} 51^{\prime} 31^{\prime \prime}$ to $77^{\circ} 23^{\prime} 51^{\prime \prime}$ E longitude on Satluj river, in Himachal Pradesh. It covers some part in Mandi and Bilaspur of the state.

\section{Sampling and Data collection}

The study based upon the primary information collected through field survey by doing proportionate random sampling of villages. Multistage simple random sampling technique was used to select the study area Fig. 1. Finally five target villages were selected. 10 per cent households were selected randomly in each village and a pretested questioner was used as a tool for gathering the information on socio-economic aspects like loss of assets (residential structures, commercial structure, cattle shed); land holdings (cultivated area owned, pasture, uncultivated barren land \& waste land); cropping pattern; livestock inventory; inventory of tree species on farm land; different sources of income including both on-farm \& off-farm sources etc.

\section{Analytical framework}

The primary data so collected during the study period were checked, scrutinized, coded, tabulated, analyzed, compiled and presented systematically by using simple tabular method. The results have been present by working out simple averages and percentages depending upon the requirement of the study.

\section{RESULTS AND DISCUSSION}

Land is the basic resource, which can be allocated for different farm and non-farm activities for maximization of household income depending upon its nature and type. Land inventory and its utilization pattern, before and after project implementation period in the sampled households have been analyzed and depicted in Table 1. The table revealed that there was a loss of total land holding per family

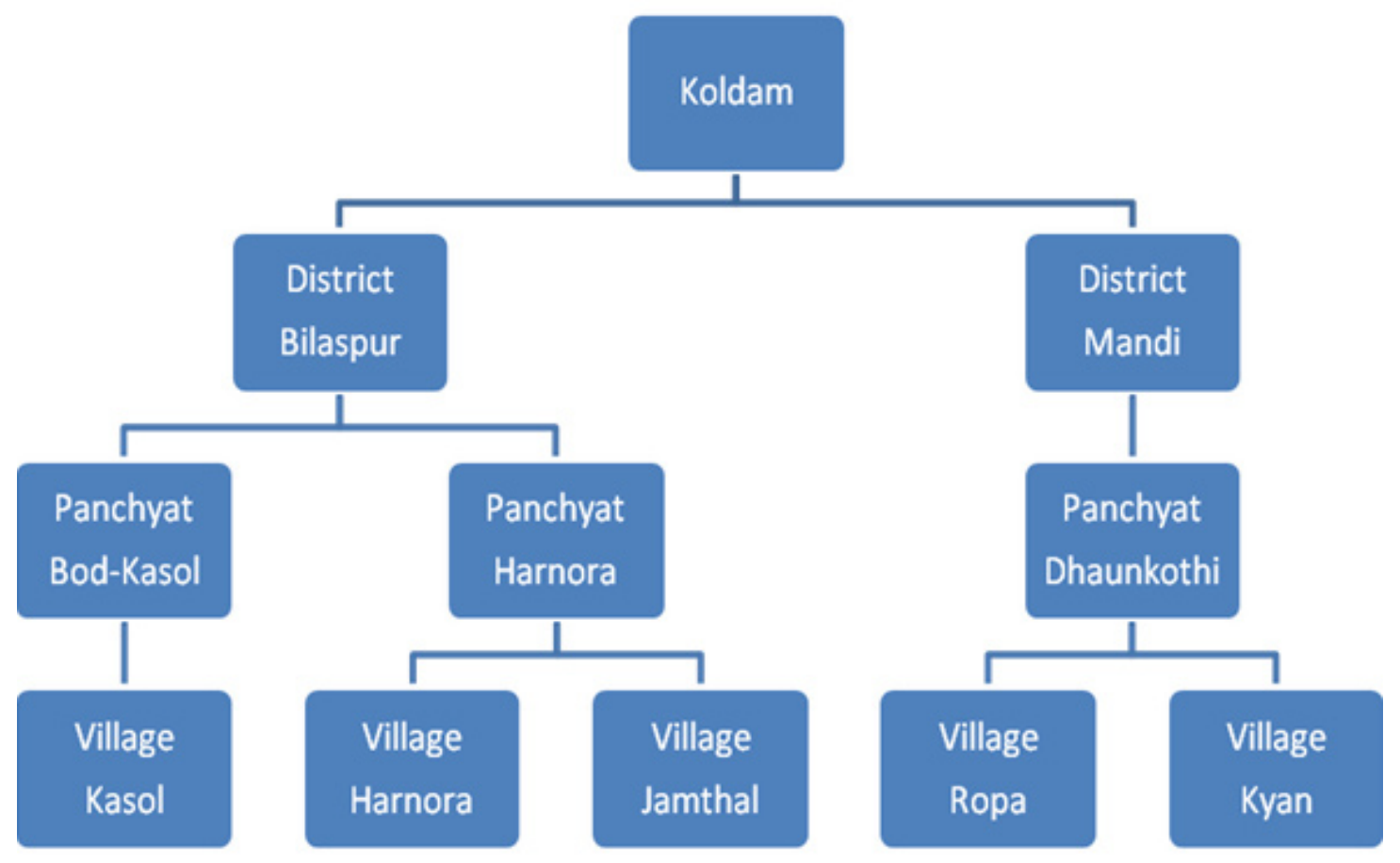

Fig. 1: Sampling procedure adopted for the selection of study area 
in the range of 33.07 to 64.46 per cent in affected villages. However in case of cultivated land there was a loss in the range of 36.15 to 67.36 per cent in sampled villages. In case of pasture, maximum loss of 60 per cent was in Kasol. It was recorded minimum $(7.50 \%)$ for village Jamthal. Similarly (Sharma 2006$)^{5}$ had also reported that 1600 hectare of cultivable land and 2000 hectare uncultivable pasture land occupied by Tehri dam project in Garhwal Himalayas of Uttrakhand. Total area under crop was decreased in the range of 67.36 to 36.15 percent in affected villages (Table 2). In a similar study conducted by Katoch et $\mathrm{al}^{4}$ on impacts of Nathpa Jhakri project in Kinnaur and Shimla district of Himachal Pradesh they also reported that area under cultivation and current fallow had decreased by 5.82 and 42.78 per cent after the implementation of the project as compared to before project implementation. Similar impact had been reported by Adams, $(1985)^{6}$ due to Bakolori dam on Skoto river, where the cropped area decreased from 82 per cent to 53 per cent. Chau, K $\mathrm{C}^{7}$ in his study "The Three Gorges project of China

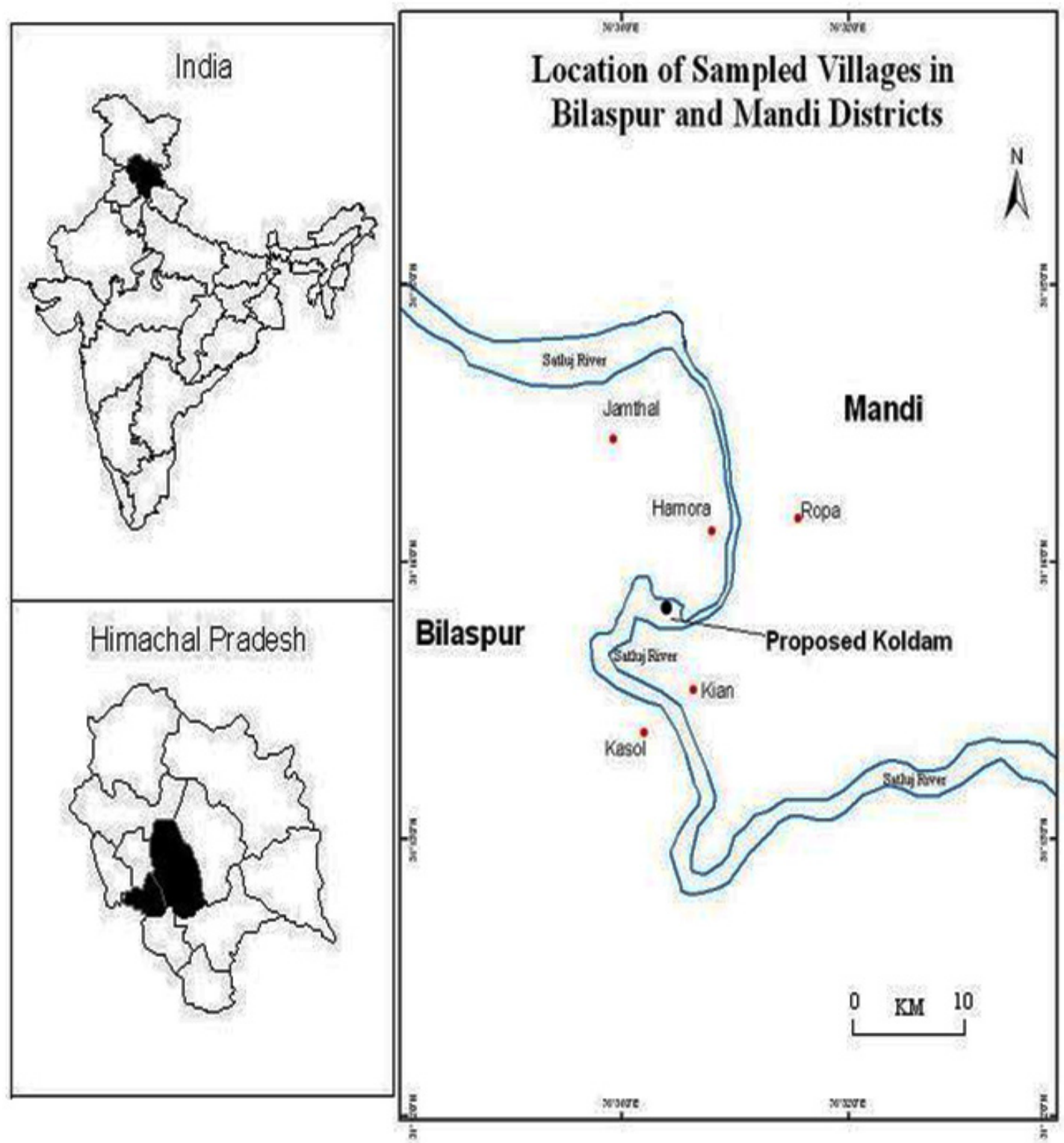

Fig. 2: Map showing location of Kol-Dam affected sampled villages 


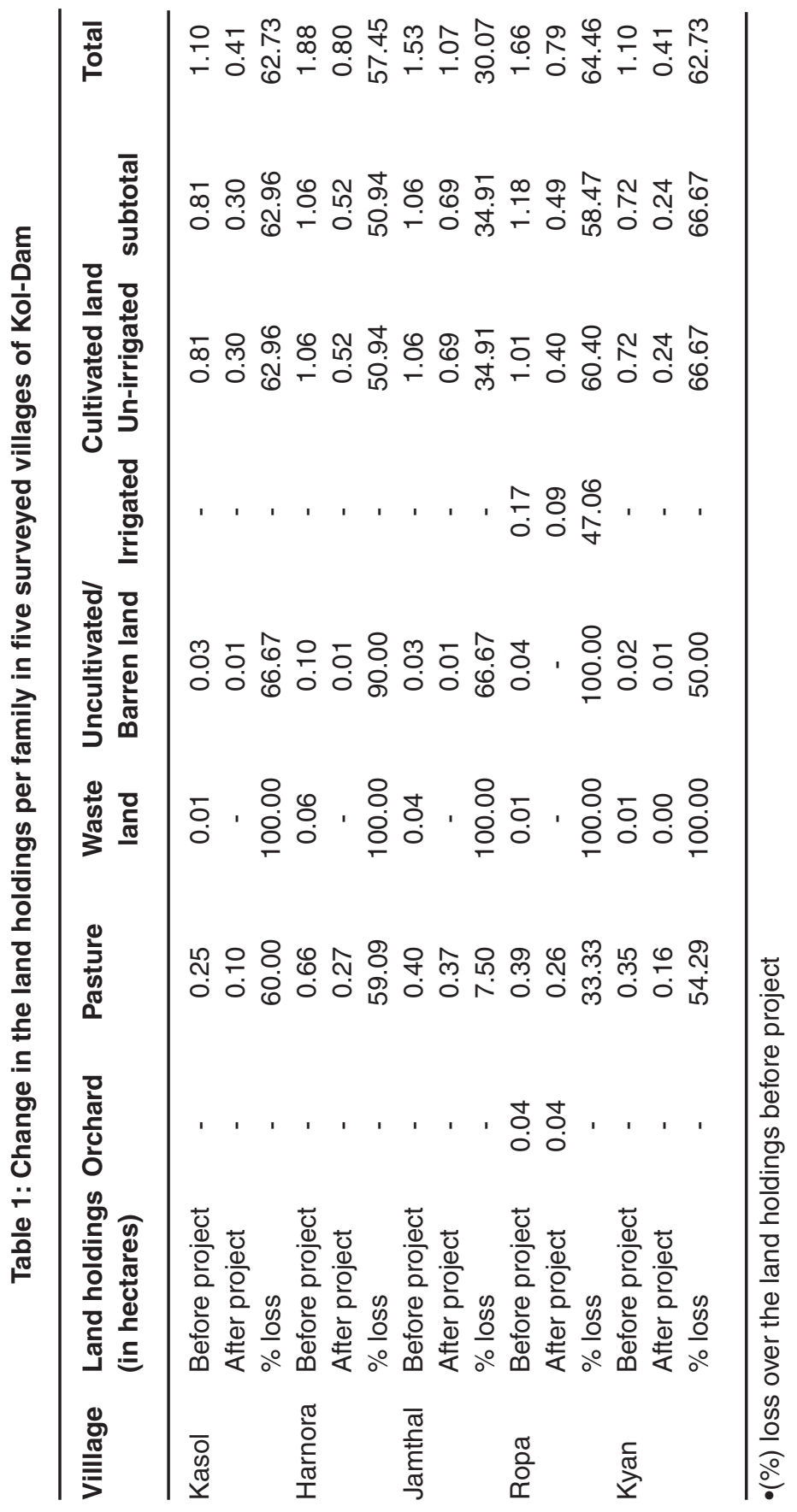




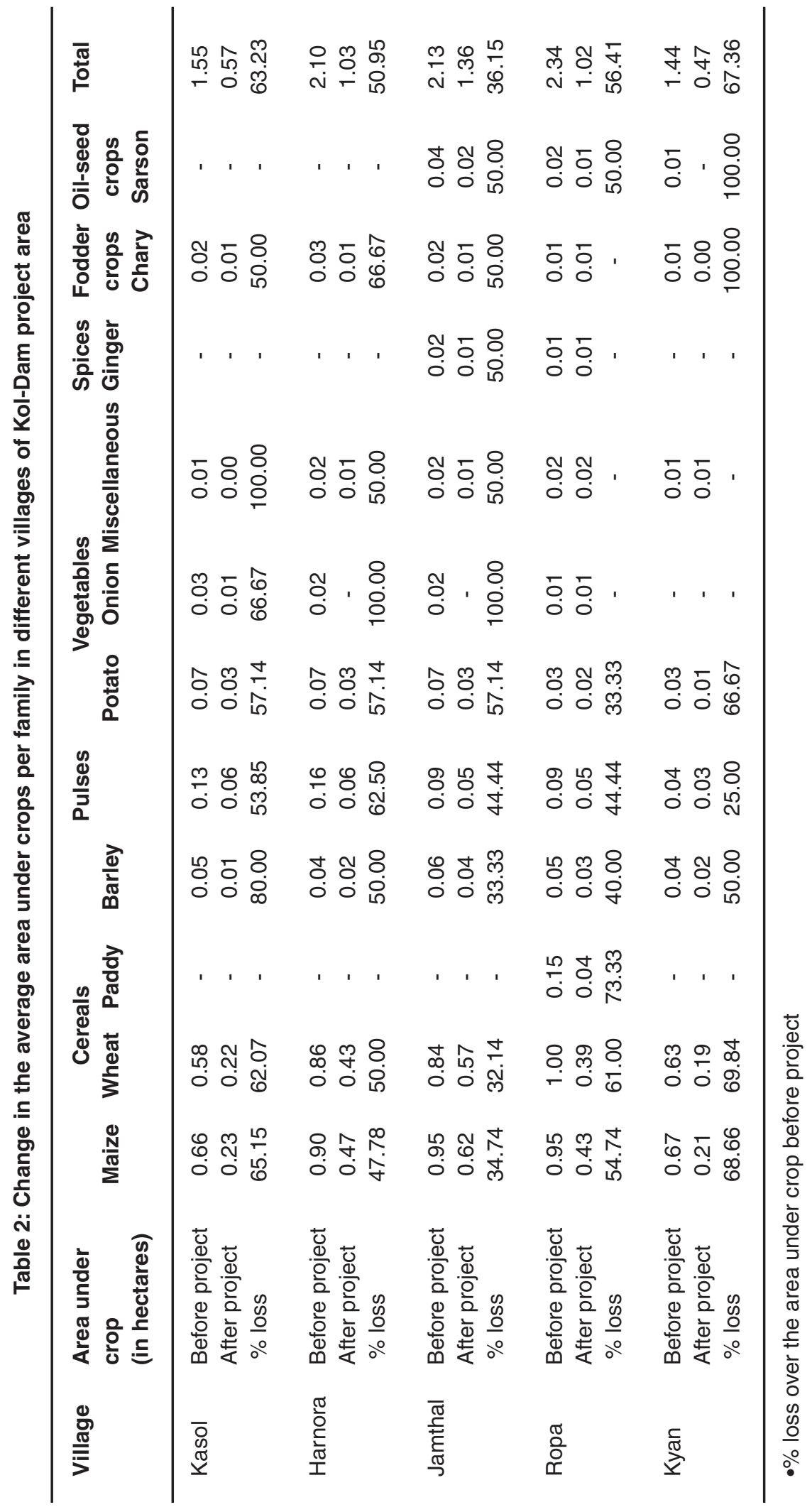




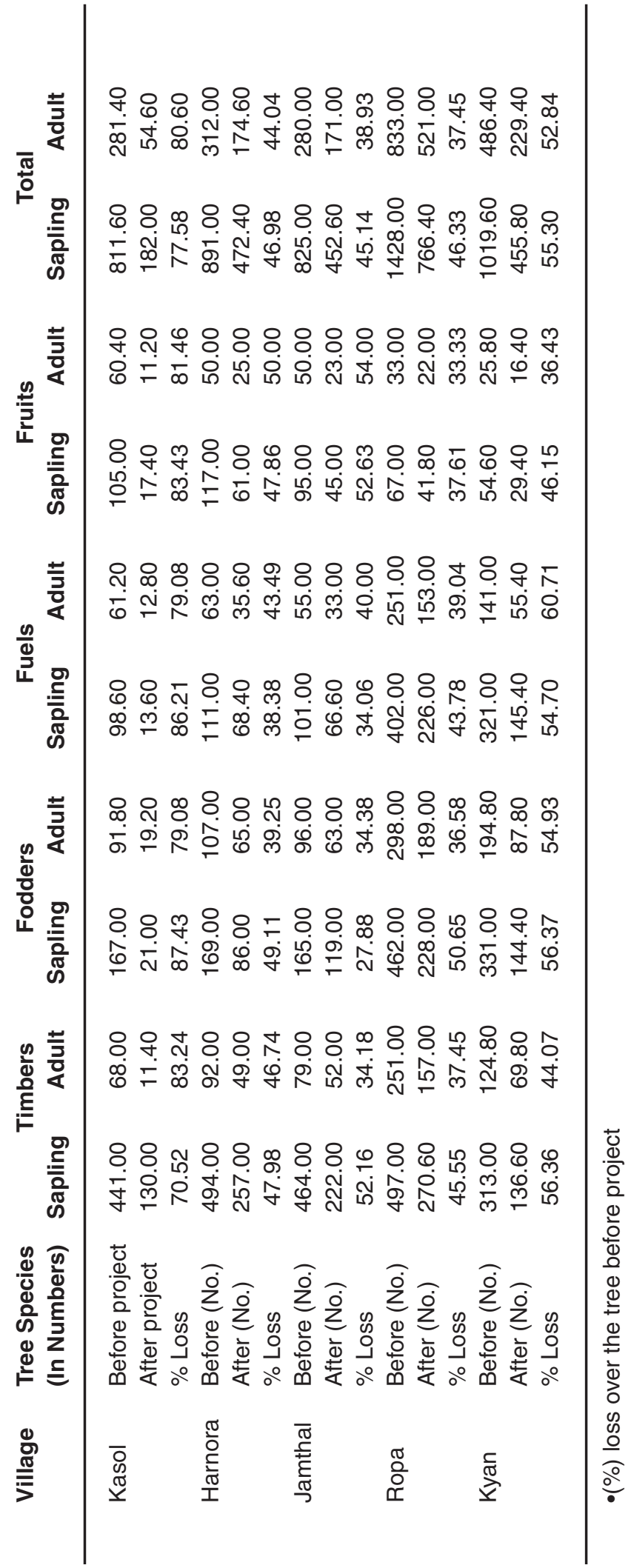




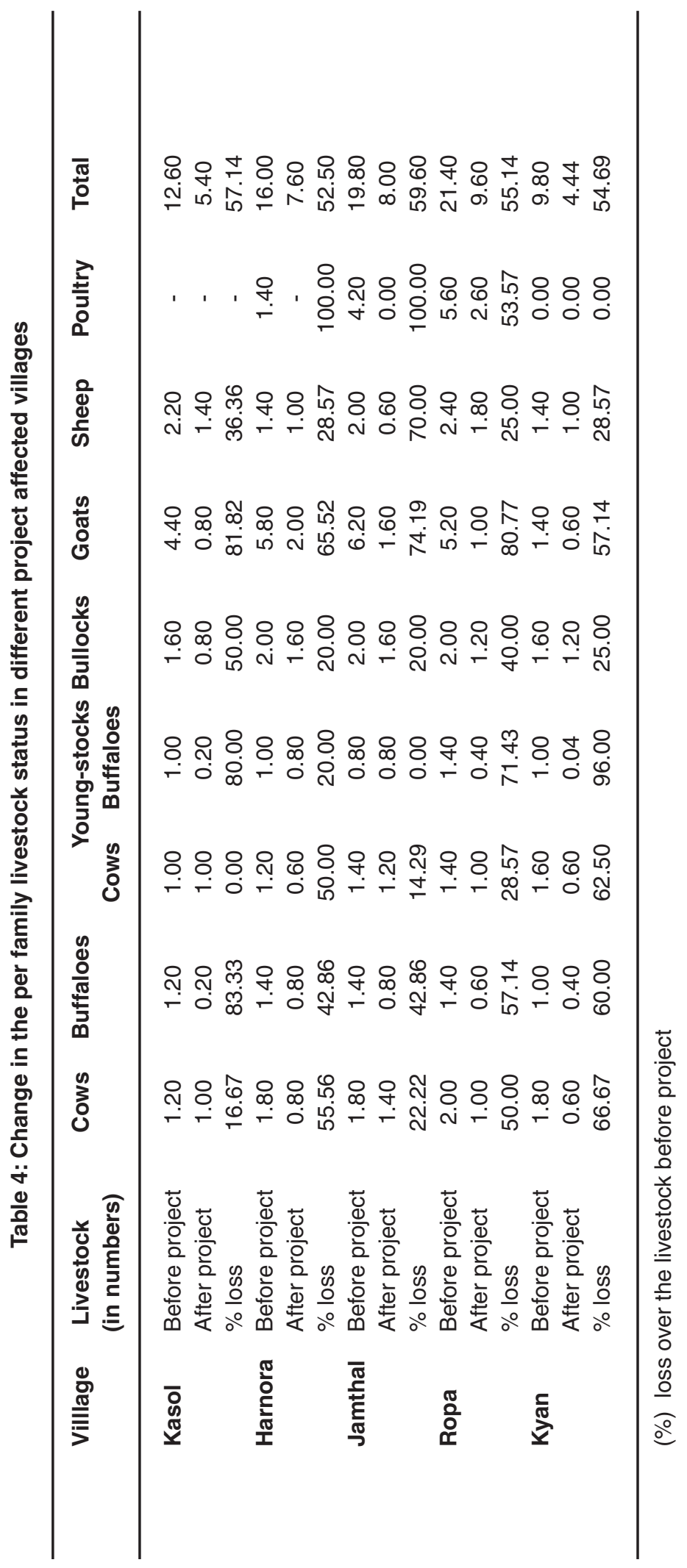




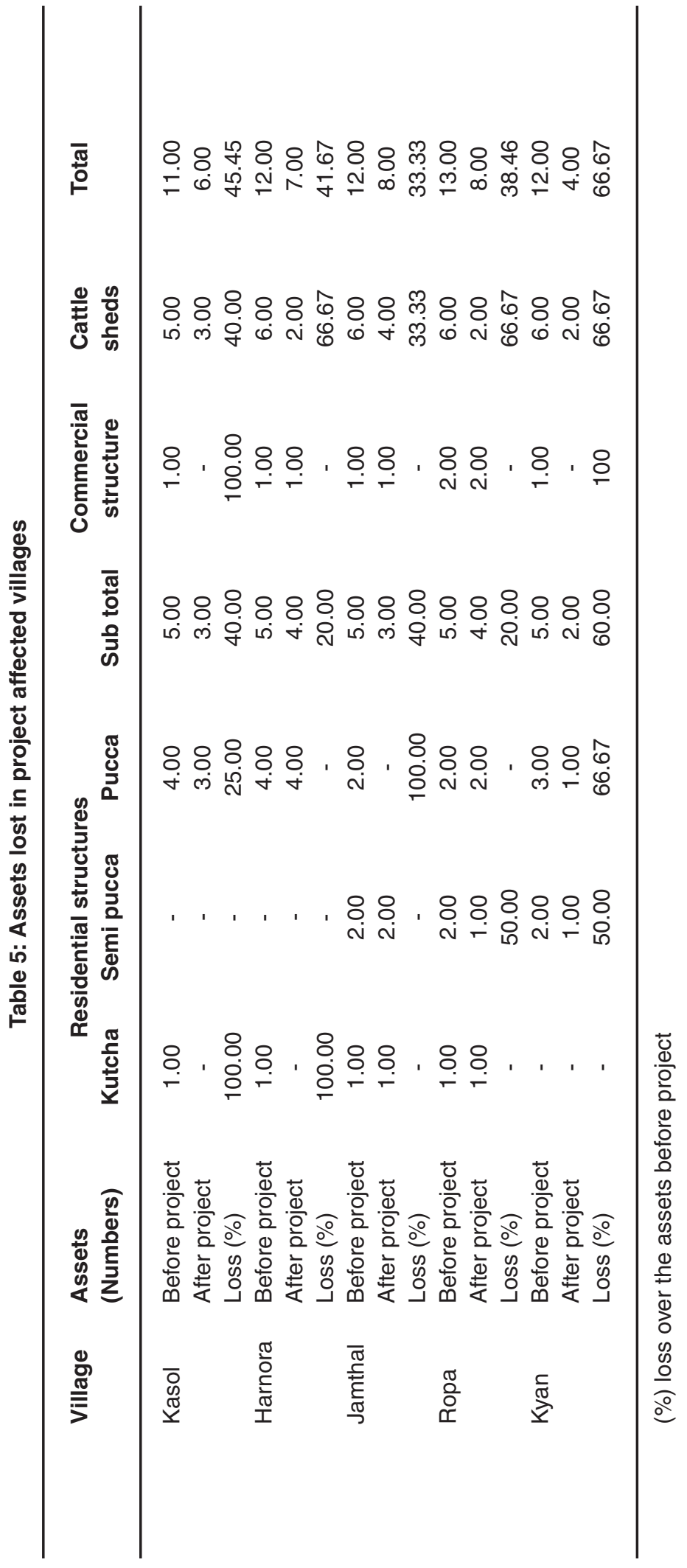




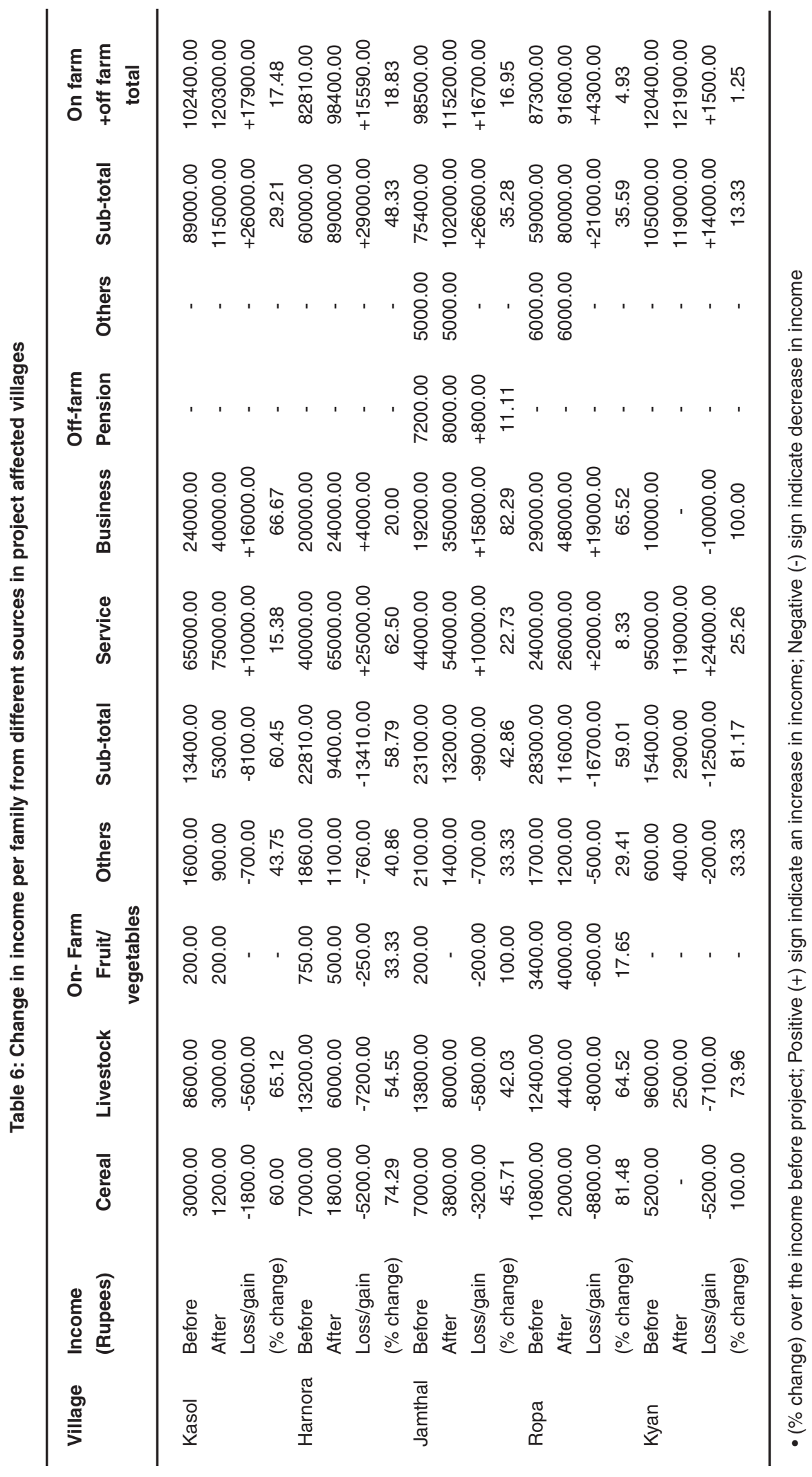


reported that this megaproject affected wholly or partly, 19 cities and counties, $238 \mathrm{~km}$ farmland, 50 $\mathrm{km}$ orange groves, as well as displacement of about $1,1,31,800$ people. Developmental projects like power projects have adverse effects on the ecology of a region and also one of the responsible factors for the extinction of land races of flora and fauna. The respondents of the study were enquired about their perceptions regarding the loss of tree species and their general view had been summarized in Table 3 and revealed that submergence of land resulted in the loss of trees (fodder, timber, fuel wood and fruit) from villages' farmland in the range of 37.45 to 80.60 per cent in affected villages. It is evident from the table that maximum 83.24 per cent of timber tree population was lost in village Kasol followed by Harnora (46.74 \%), Kyan (44.07\%), Ropa (37.45 $\%)$ and Jamthal (34.18\%). Execution of the project work has accelerated extinction of flora as compared to before project implementation periods ${ }^{4}$. Similarly, the loss of trees due to hydropower project was also reported in project report; Environmental studies for Vishnugad hydro-electric project (Anonymous $2009)^{8}$ total 6153 trees were lost due to project. As far as the total livestock per family is concerned, there was a substantial decrease in the livestock population which ranged from 52.50 to 59.60 per cent (Table 4). Construction of dam leads to the loss of fodder due to submergence of farmland, pasture/ghasni land which ultimately resulted in decrease in livestock population in each village. Dam also resulted in loss of assets i.e residential structure, commercial structure and cattle-sheds to the extent of 33.33 to 66.67 per cent in different villages (Table 5). Total asset lost due to project was maximum (66.67) in Kyan followed by Kasol (45.45 $\%)$, Harnora (41.67\%), Ropa (38.46 \%) and Jamthal
$(33.33 \%)$. This was due to the fact that earlier villages were located nearest to the dam as well as at lowest altitude than the later one where large area was submerged. Overall there was a decrease in income ranged from 42.86 to 81.17 per cent from on-farm sectors (agricultural crop \& livestock) and an increase in off farm (jobs and private business) income ranged from $13.33-48.33$ per cent has been observed in the affected villages (Table 6). Vietnam Environment Sustainable Development Center (Anonymous 2000) ${ }^{9}$ conducted a survey \& estimated that before resettlement the income of people living in Yali reservoir area in Vietnam and reported that the average annual income of households from agricultural crop, livestock before resettlement was about 6.4 million Vietnam dollars which has decreased after resettlement to 3.5 million Vietnam dollars.

\section{CONCLUSION}

It has been concluded from the present investigations that dam construction have resulted in loss of on-farm income sources like agriculture land, farm land trees and livestock population as well as associated income of project affected families from these resources was also affected in the study area.

\section{ACKNOWLEDGEMENT}

I am highly thankful to the Dean College of Forestry, Dr Y.S. Parmar University of Horticulture and Forestry, Nauni, Solan (HP). Dr. S. D. Kashyap for providing all the necessary facility related to my research work and funds through college merit scholarship. I am also thankful to Dr. S.C. Verma for his guidance and support during the study.

\section{REFERENCES}

1. Sharma, H. K. and Rana, P. K., Assessing the Impact of Hydroelectric Project construction on the Rivers of District Chamba of Himachal Pradesh in the Northwest Himalaya, India. International Research Journal of Social Sciences, 3 (2); 21-25 (2014)

2. Erlanger, T. E., Sayasone, S., Krieger, G. R., Kaul, Surinder, Sananikhom, Pany, Tanner,
M., Odermatt, P. and Utzinger, J., Baseline Health Situation of Communities Affected by the Nam Theun 2 Hydroelectric Project in Central Lao PDR and Indicators for Monitoring. International Journal of Environmental Health Research, 18 (3); 223-242 (2008)

3. Rajvanshi, Asha, Arora, Roshni, Mathur, Vinod B., Sivakumar, K. , Sathyakumar 
S., Rawat, G.S., Johnson, J.A., Ramesh, K., Dimri, NandKishor and Maletha, Ajay, Assessment of Cumulative Impacts of Hydroelectric Projects on Aquatic and Terrestrial Biodiversity in Alaknanda and Bhagirathi Basins, Uttarakhand. Wildlife Institute of India, Technical Report. 422p. (2012)

4. Katoch, Anup, Guleria, Jagtar, Kumar, Ashok, Impact of Nathpa Jhakri Hydroelectric Power Project on the Environment and Livelihood in Kinnaur and Shimla Districts of Himachal Pradesh. Research Report:71, Indian Council of Social Science Research (ICSSR), New Delhi. 118p. (2014)

5. Sharma, R. C., Hydro-Energy Resources in Garhwal Himalaya. Environmental Challenges in Central Himalaya, 2; 50-58 (2006)
6. Adams, W. M., The downstream impacts of dam construction: a case study from Nigeria. Transactions of the Institute of British Geographers N.S. 10;292-302 (1985)

7. Chau, K. C., The Three Gorges Project of China: Resettlement Prospects and Problems. Ambio; 24 (2); 98-102 (1995)

8. Anonymous, Environmental Studies for Vishnugad hydro-electric project.thdc.gov. in/writer addata, (2009).

9. Anonymous, Vietnam Environment Sustainable Development Center (VNESDC), Study on Public Participation in Resettlement Plan related to Yali Hydropower project. With the support from National Research Program KHCN07, Oxfam Hong Kong, Oxfam Quebec\& NOVIB. VNESDC, Hanoi, pp. 47-63 (2000) 